DOI.

https://doi.org/10.22219/fths.v2i1

Received: November 2018

Accepted: Desember 2018

Available online: Februari 2019

\title{
Kajian Mutu Selai Lembaran Jambu Biji (Psidium guajava) Akibat Konsentrasi Ekstrak Antosianin Bunga Mawar (Rosa sp) dan Jenis Agen Pembentuk Gel
}

\author{
Fina Innama Listin ${ }^{1}$, Elfi Anis Saati ${ }^{1}$, Rista Anggriani 1* \\ 1 Program Studi Ilmu dan Teknologi Pangan, Fakultas Pertanian Peternakan Universitas \\ Muhammadiyah Malang, Malang, Indonesia \\ *Corresponding author email : rista@umm.ac.id
}

\begin{abstract}
Guava as one of the agribusiness commodities in the primary agricultural sector, has several advantages that make this type of fruit in great demand. Proper and correct processing can increase the shelf life of horticultural products, better flavor values have an impact on the preferences and economic value more than the nutritional value contained in the processed fruit. Red guava is rich in pectin, which is very suitable to be processed into slice jam. Slice jam is the result of modification of semi-solid jam. Slice jam is known as fruit leather. The purpose of this study was to determine interaction between concentration of rose extract and the difference of gelling agent to physical and chemical characteristics of the guava slice jam. The research method used was Group Randomized Design (GRD) factorial with 2 factors. The first factor was the concentration of rose extract consisting of 5 levels $(0 \%, 2.5 \%, 5 \%, 7.5 \%, 10 \%)$. The second factor was the difference of gelling agent consisting of 2 levels (agar 1.5\% and carrageenan 1.5\%). Parameters analyzed included total soluble solid $\left({ }^{\circ}\right.$ Brix), acidity $(\mathrm{pH})$, vitamin $C$ content, antioxidant activity, total anthocyanin, texture, color intensity $(L, a+, b+)$ and hedonic test (flavour, taste, Appearance, texture). The results of this study showed that there was an interaction between the addition of rose extract concentration and the difference of gelling agent to dissolved solid ( ${ }^{\circ}$ Brix), vitamin $C$ content, antioxidant activity, total anthocyanin, brightness color intensity $(L)$ and redness $\left(a^{+}\right)$guava slice jam. The best treatment was derived at the treatment of $10 \%$ roses extract with carrageenan that had $34.20^{\circ}$ Brix of total soluble solid almost approach the standart of jam (SNI $01-3746$ 2008), 3.26 of $\mathrm{pH}, 96.56 \mathrm{mg} / \mathrm{g}$ of vitamin $\mathrm{C}, 81.45 \%$ of antioxidant power, $20.29 \mathrm{mg} / \mathrm{g}$ of level anthocyanin, 1.86 of texture, 3.13 of flavour score (quite like), 3.33 of taste score (quite tasty), 3.93 of appearance score (interesting), 2.77 of texture score (quite elastic).
\end{abstract}

Keywords: agar, carrageenan, guava, slice jam, rose extract.

\section{PENDAHULUAN}

Jambu biji merupakan buah tropis hasil pertanian hortikultura yang banyak ditanam di Indonesia. Berbagai penelitian telah banyak dilakukan untuk mengetahui berbagai manfaat dan potensi dari buah jambu biji. Pengolahan yang baik dan benar dapat meningkatkan masa simpan dari produk holtikultura, nilai cita rasa yang lebih baik berdampak pada kesukaan dan nilai ekonomis yang lebih selain dari nilai gizi yang terkandung didalam hasil olahan 
buah. Jambu biji merah kaya akan serat larut (14\%), khususnya pektin, yang sangat cocok diolah menjadi selai(Parimin, 2007).

Selai sebagai bahan pelengkap untuk makan roti dengan cara dioleskan pada roti, tetapi dirasakan kurang praktis penggunaannya dan bila dibawa bepergian, sehingga silakukan inovasi pengembangan produk baru menjadi bentuk lembaran sehingga praktis dalam penggunaannya (semacam keju lembaran) (Ismiati, 2003). Pada pembuatan selai lembaran ini dilakukan pencampuran dengan ekstrak bunga mawar. Pencampuran ini diharapkan dapat memperbaiki mutu dari selai lembaran itu sendiri dari segi warna. Selain pewarna alami kandungan antosianin pada bunga mawar merah berfungsi sebagai antioksidan sehingga diharapkan kenampakan dari selai lembaran ini menjadi menarik dan juga selai lembaran kaya akan antioksidan.

Pada studi kali ini pengaruh dari konsentrasi ekstrak antosianin bunga mawar dan penggunaan jenis agen pembentuk gel ditekankan pada kajian mutu yaitu kandungan antioksidan dan tekstur selai lembaran.

\section{METODE PENELITIAN}

Bahan

Bahan yang diperlukan padapenelitian ini antara lain jambu biji pada fase rippening dengan warna kulit hijau sedikit kekuningan yang didapat dari Pasar Merjosari, Malang, agar tepung (pa), asam sitrat (pa), karagenan (pa), bunga mawar lokal yang sudah mekar dari petani mawar di Pujon-Batu, Malang, aquades, asam sitrat, larutan iodine (teknis), amilum (pa), ethanol 70\%, serbuk DPPH (pa), KCl (pa), HCl 37\% (pa), Na-asetat (teknis).

Alat

Alat yang dipergunakan diantaranya $\mathrm{pH}$ meter tipe Lab 875 (SI Analytics), colour reader, hand refractometer tipe N1 - a merk ATAGO, spectrofotometer thermo spectronic merk GENESYS 20, spectrofotometer UV Visible tipe UV 1800 merk SHIMADZU, texture analyzer EZ Test tipe EZ-SX merk SHIMADZU. Ekstraksi pigmen mawar

Pigmen antosianin dalam bunga mawar akan diekstraksi dengan mengikuti metode yang dilakukan Saati (2014), dimana kelopak bunga mawar yang telah disortasi dan masih segar direndam dalam larutan akuades : asam sitrat (95:5). Hancuran disimpan pada suhu $10-12^{\circ} \mathrm{C}$ selama 30 menit untuk memaksimalkan proses ekstraksi. Selanjutnya dilakukan filtrasi dengan menggunakan kertas saring Whattman 41. Filtrat selanjutnya disimpan pada lemari pendingin.

\section{Pembuatan Selai Lembaran}

Proses pembuatan selai lembaran jambu biji yaitu, dengan dilakukan sortasi, pencucian terlebih dahulu kemudian dilakukan pengupasan terhadap buah jambu. Setelah dikupas kemudian daging jambu di blanching uap selama 1 
menit kemudian dihancurkan menggunakan blender dengan perbandingan air : jambu adalah 1:1. 2929 Setelah dihancurkan, saring filtrat jus jambu menggunakan saringan kelapa untuk memisahkan bijinya. Selanjutnya masukkan jus jambu dalam panci kemudian tambahkan gula 50\%, asam sitrat $0,5 \%$, setelah suhu mencapai $70{ }^{\circ} \mathrm{C}$ dimasukkan karagenan $1,5 \%$ atau agar $1,5 \%$ sebagai bahan gelling agent. Pada saat pemasakan dilakukan proses pengadukan terus menerus untuk menghomogenkan adonan. Setelah homogen matikan kompor kemudian cetak dalam loyang dan dinginkan selama 30 menit. Setelah itu dipotong lalu dimasukkan dalam plastik kemudian dilakukan analisa.

\section{Parameter Penelitian}

Parameter penelitian yang dilakukan adalah analisa bahan baku yaitu sari buah jambu biji meliputi kadar vitamin $\mathrm{C}$, aktivitas antioksidan, $\mathrm{pH}$ dan ekstrak pigmen mawar meliputi kadar antosianin, aktivitas antioksidan dan $\mathrm{pH}$. Parameter yang diamati terhadap produk selai lembaran adalah analisa kadar vitamin $\mathrm{C}$, analisa total padatan terlarut, analisa $\mathrm{pH}$, aktivitas antioksidan, kekuatan gel (tekstur), total antosianin, intensitas warna (L, a+, b+), analisa organoleptik (rasa, aroma, kenampakan, tekstur).

\section{Rancangan Percobaan dan Analisa Data}

Rancangan percobaan yang akan digunakan adalah Rancangan Acak Kelompok (RAK), yang disusun secara faktorial menggunakan 2 faktor yaitu faktor I adalah konsentrasi ekstrak antosianin bunga mawar $(0 \%, 2,5 \%, 5 \%$, $7,5 \%, 10 \%$ ) dan faktor II adalah jenis agen pembentuk gel (karagenan, agar).

Pengolahan data pada penelitian ini akan dilakukan dengan menggunaka Microsoft Excel, dengan menggunakan analisis ragam pada taraf $5 \%$ dan $1 \%$. Selanjutnya bila terjadi beda nyata atau interaksi pada masing-masing perlakuan maka data yang sudah diperoleh akan dilanjutkan dengan uji pembeda menggunakan uji DMRT (Duncan's Multiple Range Test) pada taraf $5 \%$, dan $1 \%)$.

\section{HASIL DAN PEMBAHASAN}

\section{Hasil Analisa Bahan Baku}

Sebelum digunakan untuk pembuatan selai lembaran dilakukan analisis terlebih dahulu terhadap jus jambu biji dan ekstrak antosianin bunga mawar sebagai bahan baku pembuatan selai lembaran. 
Tabel 1. Analisa Bahan Baku Pada Jus Jambu Biji dan Ekstrak Bunga Mawar

\begin{tabular}{|c|c|c|c|c|}
\hline \multirow[t]{2}{*}{ Parameter } & \multicolumn{2}{|c|}{ Jus Jambu Biji } & \multicolumn{2}{|c|}{ Ekstrak Bunga Mawar } \\
\hline & Analisis & Literatur & Analisis & Literatur \\
\hline $\begin{array}{l}\text { Kadar Vitamin C } \\
(\mathrm{mg} / \mathrm{g})\end{array}$ & 98,32 & $87,00 \mathrm{a}$ & - & - \\
\hline $\begin{array}{l}\text { Daya Antioksida } \\
\text { (\% inhibisi) }\end{array}$ & 81,51 & - & 63,87 & $63,14 \mathrm{~b}$ \\
\hline $\begin{array}{ll}\text { Total } & \text { Antosianin } \\
(\mathrm{mg} / \mathrm{g}) & \end{array}$ & - & - & 126,24 & - \\
\hline $\mathrm{pH}$ & 2,79 & $2,93 \mathrm{c}$ & 3,23 & $2,15 \mathrm{~d}$ \\
\hline
\end{tabular}

Hasil analisa jus buah jambu biji kadar vitamin c menghasilkan kadar vitamin c yang lebih tinggi daripada literatur. Menurut Hadisaputra (2012) kadar vitamin c jus buah jambu biji yaitu $87 \mathrm{mg} / 100 \mathrm{~g}$ jambu biji. Derajat keasamaan jus buah jambu biji yaitu 2,79 berdasarkan hasil analisa, menurut Afani (2016) kandungan $\mathrm{pH}$ jus buah jambu biji yaitu 2,97. Hasil analisa ekstrak mawar kadar antosianin 126,24 mg/g. Menurut Saati (2011) kadar antioksidan ekstrak mawar yaitu 63,14. Prbedaan ini terjadi karena diduga jenis mawar yang digunakan tidak sama denga literatur. Derajat keasamaan ekstrak mawar yaitu 3,23 berdasarkan hasil analisa, menurut Saati (2012) kandungan $\mathrm{pH}$ ekstrak mawar yaitu 2,15 .

\section{Analisa Kimia Produk Selai Lembaran}

\section{Total Padatan Terlarut}

Hasil sidik ragam menunjukkan bahwa terjadi interaksi antara penambahan konsentrasi ekstrak mawar dengan perbedaan gelling agent terhadap total padatan terlarut selai lembaran jambu biji dan memiliki nilai yang berbeda sangat nyata. Nilai total padatan terlarut paling tinggi terdapat pada perlakuan tanpa penambahan ekstrak mawar, hal ini diduga karena dengan adanya penambahan ekstrak mawar akan menyebabkan selai lembaran menjadi sedikit lebih asam, yang mengakibatkan kandungan sukrosa juga menurun (Prasetyo, 2013). Total padatan terlarut pada selai lembaran jambu biji yang masih rendah ini diduga karena, pada saat melakukan analisa, selai lembaran dihancurkan dan juga dilakukan pengenceran dengan perbandingan bahan dan akuades 1:2. Sehingga 43 kemungkinan pada saat pengenceran total padatan terlarut banyak yang ikut terlarut pada saat pengenceran sehingga yang terhitung dalam selai lembaran hanya sedikit. Selain itu pada selai lembaran terdapat agar dan karagenan, dimana kedua hidrokoloid ini dapat menyerap air, yang mengakibatkan padatan yang terlarut hanya sedikit (Putri, 2013). 


\section{Kadar Vitamin C}

Hasil sidik ragam menunjukkan bahwa terdapat interaksi antara penambahan ekstrak mawar dengan perbedaan gelling agent terhadap kadar Vitamin $\mathrm{C}$ selai lembaran jambu biji dan memiliki nilai yang berbeda sangat nyata. Kadar vitamin C dari setiap perlakuan memiliki nilai yang berbeda sangat nyata, perbedaan ini dipengaruhi oleh perbedaan penambahan konsentrasi ekstrak mawar dan perbedaan gelling agent yang digunakan. Hal ini dikarenakan peningkatan konsentrasi karagenan yang ditambahkan berhubungan dengan sifat karagenan yang sangat mudah mengikat molekulmolekul air juga senyawa-senyawa lain seperti vitamin C, asam-asam organik, yang terdapat di dalam campuran, sehingga senyawa yang mudah menguap dan rusak oleh proses pengolahan dapat dihambat sebagian dengan penambahan karagenan (Winarno, 2004). Rendah tingginya kadar vitamin C dapat terjadi karena dipengaruhi oleh kadar antosianin dan nilai $\mathrm{pH}$ ekstraknya. Menurut Saati (2014), keberadaan pigmen antosianin menekan terjadinya kehilangan vitamin C pada bahan. Penambahan kadar gula 40\%, 50\% dan $60 \%$ menunjukkan kadar vitamin C yang semakin menurun yakni $90 \mathrm{mg} / 100 \mathrm{~g}$, $80 \mathrm{mg} / 100 \mathrm{~g}$ dan $60 \mathrm{mg} / 100 \mathrm{~g}$.

Tabel 2. Total Padatan Terlarut dan Kadar Vitamin C Selai Lembaran

\begin{tabular}{lcc}
\hline \multicolumn{1}{c}{ Peralakuan } & $\begin{array}{c}\text { Total Padatan Terlarut } \\
\left({ }^{\circ} \text { Brix }\right)\end{array}$ & $\begin{array}{c}\text { Kadar Vitamin C } \\
(\mathrm{mg} / \mathrm{g})\end{array}$ \\
\hline Mawar 0\%+Agar & $42,34 \mathrm{~d}$ & $78,10 \mathrm{ab}$ \\
Mawar 0\%+Karagenan & $40,34 \mathrm{~cd}$ & $76,86 \mathrm{a}$ \\
Mawar 2,5\%+Agar & $37,00 \mathrm{c}$ & $77,75 \mathrm{a}$ \\
Mawar 2,5\%+Karagenan & $37,14 \mathrm{c}$ & $76,94 \mathrm{a}$ \\
Mawar 5\%+Agar & $30,34 \mathrm{~b}$ & $87,05 \mathrm{c}$ \\
Mawar 5\%+karagenan & $41,34 \mathrm{~cd}$ & $79,22 \mathrm{~b}$ \\
Mawar 7,5\%+Agar & $24,40 \mathrm{a}$ & $77,79 \mathrm{c}$ \\
Mawar 7,5\%+Karagenan & $35,94 \mathrm{c}$ & $78,55 \mathrm{ab}$ \\
Mawar 10\%+Agar & $37,54 \mathrm{c}$ & $94,10 \mathrm{~d}$ \\
Mawar 10\%+Karagenan & $34,20 \mathrm{c}$ & $96,56 \mathrm{e}$ \\
\hline
\end{tabular}

\section{Daya Antioksidan}

Hasil sidik ragam menunjukkan bahwa terdapat interaksi antara penambahan ekstrak mawar dengan perbedaan gelling agent terhadap aktivitas antioksidan selai lembaran jambu biji dan memiliki nilai yang berbeda sangat nyata. Daya antioksidan yang terdapat dalam selai lembaran diakibatkan adanya kandungan vitamin $\mathrm{C}$ buah jambu biji dan kandungan antosianin dari penambahan ekstrak mawar (Saati, 2016). Semakin besar konsentrasi ekstrak mawar maka aktivitas antioksidan juga akan semakin semakin besar, besar 
kecilnya aktivitas antioksidan disebabkan oleh proses pengolahan pembuatan selai, dimana terdapat proses pemanasan yang dapat menurunkan kandungan antioksidan, karena antioksidan tidak tahan terhadap suhu panas (Isnaini, 2010). Penggunaan agen pembentuk gel juga dapat mempengaruhi antivitas antioksidan dari selai lembaran.

\section{Kadar Antosianin}

Hasil sidik ragam menunjukkan bahwa terdapat interaksi antara penambahan ekstrak mawar dengan perbedaan gelling agent terhadap kadar antosianin selai lembaran jambu biji dan memiliki nilai yang berbeda sangat nyata. Semakin besar konsentrasi mawar yang ditambahkan maka, semakin besar kandungan antosianin, karena terdapat pigmen antosianin dalam bunga mawar (Saati, 2016). Selain penambahan ekstrak mawar, penggunaan gelling agent yang digunakan mempengaruhi kadar antosianin dalam selai lembaran jambu biji. Hal ini dikarenakan peningkatan konsentrasi karagenan yang ditambahkan berhubungan dengan sifat karagenan yang sangat mudah mengikat molekul-molekul air juga senyawa-senyawa lain seperti vitamin $\mathrm{C}$, asam-asam organik (Winarno, 2004).

Tabel 3. Daya Antioksidan dan Kadar Antosianin Selai Lembaran

\begin{tabular}{llc}
\hline \multicolumn{1}{c}{ Perlakuan } & \% Inhibisi & $\begin{array}{c}\text { Kadar Antosianin } \\
(\mathrm{mg} / \mathrm{g})\end{array}$ \\
\hline Mawar 0\%+Agar & $83,19 \mathrm{c}$ & $1,45 \mathrm{a}$ \\
Mawar 0\%+Karagenan & $83,84 \mathrm{c}$ & $2,78 \mathrm{~b}$ \\
Mawar 2,5\%+Agar & $84,36 \mathrm{~cd}$ & $3,84 \mathrm{c}$ \\
Mawar 2,5\%+Karagenan & $85,51 \mathrm{~d}$ & $6,01 \mathrm{~d}$ \\
Mawar 5\%+Agar & $84,23 \mathrm{~cd}$ & $7,85 \mathrm{e}$ \\
Mawar 5\%+karagenan & $83,66 \mathrm{c}$ & $8,52 \mathrm{f}$ \\
Mawar 7,5\%+Agar & $85,26 \mathrm{~cd}$ & $11,97 \mathrm{~g}$ \\
Mawar 7,5\%+Karagenan & $75,72 \mathrm{a}$ & $13,30 \mathrm{~h}$ \\
Mawar 10\%+Agar & $84,60 \mathrm{~cd}$ & $26,54 \mathrm{i}$ \\
Mawar 10\%+Karagenan & $81,45 \mathrm{~b}$ & $28,59 \mathrm{j}$ \\
\hline
\end{tabular}

\section{Nilai $\mathrm{pH}$}

Penggunaan jenis gelling agent berpengaruh sangat nyata terhadap nilai $\mathrm{pH}$ selai lembaran. Nilai $\mathrm{pH}$ dengan perlakuan karagenan memiliki nilai $\mathrm{pH}$ yang lebih besar dari perlakuan dengan agar. Hal ini terjadi karena dalam karagenan terdapat gugus anhidrogalaktosa yang menyebabkan daya dispersi terhadap air berkurang, hasil penelitian ini selaras dengan literatur. Menurut Fachruddin (1977) menyatakan bahwa nilai $\mathrm{pH}$ kombinasi perlakuan agar-agar lebih rendah (keasaman lebih tinggi) dibandingkan perlakuan karagenan. 


\section{Tekstur}

Penggunaan jenis gelling agent berpengaruh sangat nyata terhadap tekstur selai lembaran. Gelling agent merupakan komponen polimer dengan bobot molekul tinggi yang merupakan gabungan molekul-molekul dan lilitan-lilitan molekul polimer yang akan memberikan sifat kental dan gel yang diinginkan. Molekul primer berikatan melalui ikatan saling membentuk struktur jaringan tiga dimensi dengan molekul pelarut terperangkap dalam jaringan (Erdinawati, 2006). Gel dapat terbentuk karena adanya pengikatan silang rantai-rantai polimer sehingga terbentuk suatu jala tiga dimensi bersambungan. Selanjutnya jala ini menangkap atau mengimobilisasikan air di dalamnya dan membentuk struktur yang kuat dan kaku. Gel mempunyai sifat seperti padatan, khususnya sifat elastis dan kekakuan (Winarno, 1990).

Tabel 4. Nilai $\mathrm{pH}$ dan Tekstur Selai Lembaran

\begin{tabular}{lcc}
\hline \multicolumn{1}{c}{ Perlakuan } & $\mathrm{pH}$ & Kekuatan Gel (Tekstur) (N) \\
\hline Agar & $4,37 \mathrm{a}$ & $1,51 \mathrm{a}$ \\
Karagenan & $4,86 \mathrm{~b}$ & $3,34 \mathrm{~b}$ \\
\hline
\end{tabular}

\section{Tingkat Kecerahan (L)}

Hasil sidik ragam menunjukkan bahwa terdapat interaksi antara penambahan ekstrak mawar dengan perbedaan gelling agent terhadap tingkat kecerahan (L) selai lembaran jambu biji dan memiliki nilai yang berbeda sangat nyata. Perlakuan yang menggunakan karagenan cenderung memiliki tingkat kecerahan yang lebih besar daripada menggunakan agar. Semakin banyak penambahan konsentrasi ekstrak mawar memiliki tingkat kecerahan yang semakin rendah. Hal ini terjadi karena, dengan adanya penambahan ekstrak mawar, maka selai akan menjadi semakin merah karena di dalam mawar terdapat pigmen antosianin yang menyebabkan warna merah semakin pekat, sehingga tingkat kecerahan menurun. Menurut Putri dkk (2013), menyatakan bahwa kombinasi perlakuan karagenan menghasilkan gel yang berwarna semakin gelap sesuai dengan peningkatan konsentrasi $(2,5 \% ; 3 \% ; 3,5 \%)$. Penambahan agar-agar akan menghasilkan gel yang berwarna jernih (Tranggono dkk, 1990) sedangkan penambahan dari karagenan akan menghasilkan gel berwarna lebih gelap (Fardiaz, 1989). 
Tabel 5. Intensitas Warna Selai Lembaran

\begin{tabular}{lccc}
\hline \multicolumn{1}{c}{ Peralakuan } & $\begin{array}{c}\text { Tingkat Kecerahan } \\
(\mathrm{L})\end{array}$ & $\begin{array}{c}\text { Tingkat } \\
\text { Kemerahan (a+) }\end{array}$ & $\begin{array}{c}\text { Tingkat } \\
\text { Kekuningan } \\
(\mathrm{b}+)\end{array}$ \\
\hline Mawar 0\%+Agar & $40,97 \mathrm{~d}$ & $5,87 \mathrm{a}$ & $8,63 \mathrm{~d}$ \\
Mawar 0\%+Karagenan & $44,73 \mathrm{e}$ & $7,00 \mathrm{~b}$ & $12,70 \mathrm{e}$ \\
Mawar 2,5\%+Agar & $35,43 \mathrm{~b}$ & $11,53 \mathrm{c}$ & $8,30 \mathrm{~b}$ \\
Mawar 2,5\%+Karagenan & $37,03 \mathrm{c}$ & $14,50 \mathrm{~d}$ & $4,57 \mathrm{c}$ \\
Mawar 5\%+Agar & $35,27 \mathrm{~b}$ & $14,63 \mathrm{~d}$ & $2,63 \mathrm{~b}$ \\
Mawar 5\%+karagenan & $36,13 \mathrm{bc}$ & $20,20 \mathrm{f}$ & $3,30 \mathrm{bc}$ \\
Mawar 7,5\%+Agar & $34,83 \mathrm{ab}$ & $17,97 \mathrm{e}$ & $2,80 \mathrm{ab}$ \\
Mawar 7,5\%+Karagenan & $34,20 \mathrm{ab}$ & $24,33 \mathrm{~g}$ & $2,30 \mathrm{ab}$ \\
Mawar 10\%+Agar & $33,77 \mathrm{a}$ & $24,43 \mathrm{~g}$ & $0,27 \mathrm{a}$ \\
Mawar 10\%+Karagenan & $35,33 \mathrm{~b}$ & $18,53 \mathrm{e}$ & $0,57 \mathrm{~b}$ \\
\hline
\end{tabular}

\section{Tingkat Kemerahan (a+)}

Hasil sidik ragam menunjukkan bahwa terdapat interaksi antara penambahan ekstrak mawar dengan perbedaan gelling agent terhadap tingkat kemerahan (a+) selai lembaran jambu biji dan memiliki nilai yang berbeda sangat nyata. Menurut Saati (2014), menyatakan bahwa pigmen antosianin dari ekstrak bunga mawar paling stabil terdapat pada buffer $\mathrm{pH} 3,75$ dan ekstrak pigmen antosianin menyumbang warna kemerahan $2-3 \%$ pada produk yoghurt, selai dan minuman berkarbonat. Gelling agent yang digunakan adalah karagenan dan agar, keduanya mempengaruhi tingkat kemerahan karena karagenan dan agar dapat mengikat air dalam bahan sehingga asam dalam bahan juga akan ikut terikat, sehingga ekstrak antosianin bunga mawar merah akan ikut terikat dalam karagenan yang mengakibatkan tingkat kemerahan pada perlakuan karagenan cenderung lebih tinggi.

\section{Tingkat Kekuningan (b+)}

Hasil sidik ragam menunjukkan bahwa terdapat interaksi antara penambahan ekstrak mawar dengan perbedaan gelling agent terhadap tingkat kekuningan $(\mathrm{b}+)$ selai lembaran jambu biji dan memiliki nilai yang berbeda sangat nyata. Semakin banyak konsentrasi ekstrak mawar yang ditambahkan maka semakin rendah nilai warna kekuningan pada selai, hal ini dikarenakan oleh kandungan antosianin pada mawar, semakin banyak ekstrak yang ditambahkan membuat warna kemerahan semakin tinggi namun warna kekuningan semakin rendah. Putri dkk (2013), menyatakan bahwa kombinasi perlakuan karagenan menghasilkan gel yang berwarna semakin gelap sesuai dengan peningkatan konsentrasi $(2,5 \% ; 3 \% ; 3,5 \%)$. Penambahan agar-agar akan 
menghasilkan gel yang berwarna jernih (Tranggono dkk, 1990) sedangkan penambahan dari karagenan akan menghasilkan gel berwarna lebih gelap.

\section{Aroma}

Hasil sidik ragam pada (Lampiran 10) menunjukkan bahwa tidak terjadi interaksi antara penambahan ekstrak mawar dengan perbedaan gelling agent terhadap skor aroma selai lembaran jambu biji dan memiliki nilai yang tidak berbeda nyata. Pembuatan selai lembaran ini berbahan dasar jambu biji dengan adanya penambahan ekstrak antosianin mawar, aroma yang diharapkan dari selai ini adalah aroma khas dari buah jambu biji itu sendiri. Semakin tiggi penambahan konsentrasi ekstrak antosianin bunga mawar pada selai lembaran jambu biji maka, aroma dari selai lembaran lebih dominan aroma mawar dari pada aroma jambu biji sendiri. Menurut Fitrianto (2006) dengan adanya penambahan konsentrasi gula yang sama akan menghasilkan aroma karamelisasi lebih kuat.

\section{Rasa}

Hasil sidik ragam pada menunjukkan bahwa tidak terjadi interaksi antara penambahan ekstrak mawar dengan perbedaan gelling agent terhadap skor rasa selai lembaran jambu biji dan memiliki nilai yang tidak berbeda nyata. Rata-rata dari skor rasa berkisar antara 2,80 hingga 3,33 (cukup enak), diduga yang menyebabkan rasa kurang enak adalah pengaruh dari ekstrak mawar. Menurut Winarno (2008), menyatakan bahwa rasa dipengaruhi oleh pengaruh interaksi antara komponen rasa lainnya seperti adanya penambahan gula pasir dan asam sitrat.

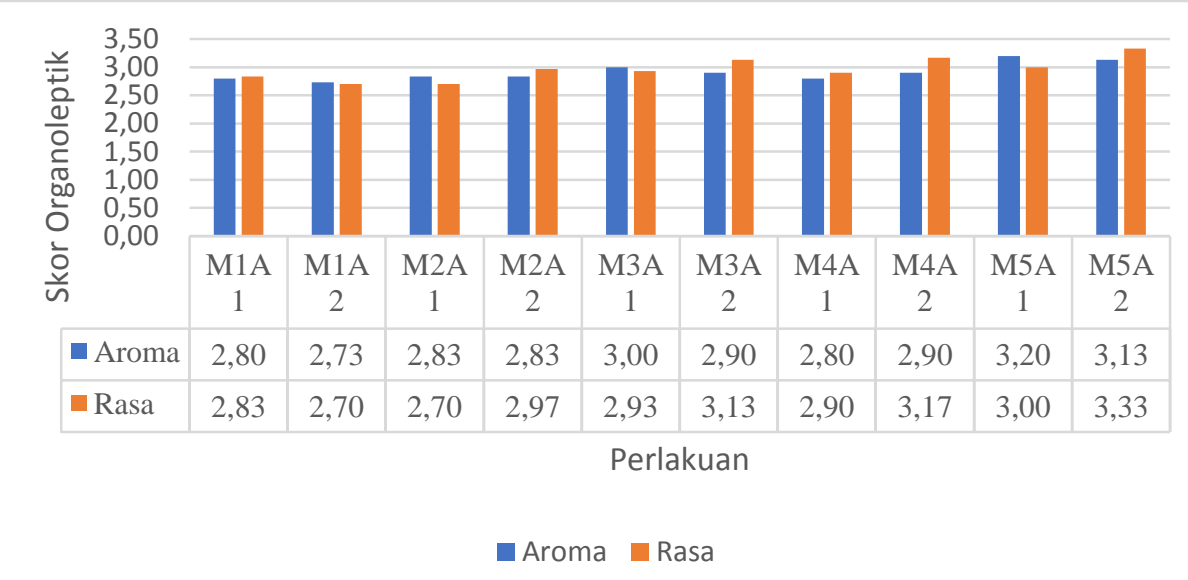

Gambar 1. Histogram Organoleptik Aroma dan Rasa Selai Lembaran

Keterangan : 1. Sangat tidak suka/sangat tidak enak, 2. Tidak suka/tidak enak, 3. Cukup suka/cukup enak, 4. Suka/enak, 5. Sangat suka/sangat enak 


\section{Kenampakan}

Konsentrasi Ekstrak antosianin mawar berpengaruh sangat nyata terhadap skor kenampakan selai lembaran. Penambahan ekstrak antosianin mawar dapat mempengaruhi skor kenampakan dari selai lembaran jambu biji, karena bunga mawar sendiri menymbangkan warna merah dimana dalam mawar terdapat pigmen alami yang disebut antosianin. Menurut Andarwulan dan Faradila, (2012), antosianin merupakan pigmen yang memberi karakteristik warna merah, ungu, dan biru dan terdapat pada tumbuhan.

\section{Kekuatan Gel (Tekstur)}

Konsentrasi Ekstrak antosianin mawar berpengaruh sangat nyata terhadap skor tekstur selai lembaran. Hal ini diduga karena, selama proses ekstraksi bunga mawar bahan yang digunakan adalah asam sitrat, penambahan ekstrak mawar pada selai lembaran dapat mempengaruhi keasaman dari selai tersebut.

Tabel 6. Skor Organoleptik Kenampakan dan Kekuatan Gel Selai Lembaran

\begin{tabular}{lcc}
\hline Perlakuan & Kenampakan & Kekuatan gel (Tekstur) \\
\hline Mawar 0\% & $1,32 \mathrm{a}$ & $1,11 \mathrm{a}$ \\
Mawar 2,5\% & $1,66 \mathrm{~b}$ & $1,29 \mathrm{~b}$ \\
Mawar $5 \%$ & $1,88 \mathrm{c}$ & $1,49 \mathrm{c}$ \\
Mawar $7,5 \%$ & $2,16 \mathrm{~d}$ & $1,47 \mathrm{c}$ \\
Mawar $10 \%$ & $2,31 \mathrm{e}$ & $1,47 \mathrm{c}$ \\
\hline Agar & $4,61 \mathrm{a}$ & $3,20 \mathrm{a}$ \\
Karagenan & $4,72 \mathrm{a}$ & $3,63 \mathrm{~b}$ \\
\hline
\end{tabular}

Keterangan : 1. Sangat tidak menarik/ Sangat tidak elastis, 2. Tidak menarik/ Tidak elastis, 3. Cukup menarik/ Cukup elastis, 4. Menarik/Elastis, 5. Sangat menarik/ Sangat elastis

Perbedaan gelling agent berpengaruh sangat nyata terhadap skor tekstur selai lembaran. Hal ini sesuai dengan pendapat Erdinawati (2006) gelling agent merupakan senyawa polimer yang memiliki molekul tinggi dan merupakan gabungan molekul-molekul polimer yang akan memberikan sifat kental serta gel yang diinginkan. Molekul-molekul primer akan saling berikatan dan membentuk struktur jaringan tiga dimensi dengan molekul pelarut yang terperangkap dalam jaringan.

\section{KESIMPULAN}

Perlakuan terbaik dihasilkan oleh kombinasi perlakuan selai lembaran penambahan ekstrak bunga mawar 10\% dengan karagenan yang mempunyai nilai total padatan terlarut $34,20^{\circ}$ Brix, $\mathrm{pH} 3,26$, kadar vitamin $\mathrm{C} 96,56 \mathrm{mg} / \mathrm{g}$, 
daya antioksidan $81,45 \%$, total antosianin 20,26 mg/g, ekstur 1,86, tingkat kecerahan (L) 35,33, tingkat kemerahan (a+) 18,5, tingkat kekuningan (b+) 0,57, skor aroma 3,13 (cenderung cukup suka), skor rasa 3, 33 (cenderung cukup enak), skor kenampakan 3,93 (cenderung menarik), skor tekstur 2,77 (cenderung cukup elastis).

\section{REFERENSI}

Afani, Feby, N. (2016). Pengaruh Perbandingan Jambu Biji (Psidium guajava L.) Dengan Rosella (Hibiscus sabdariffa Linn) Dan Jenis Jambu Biji Terhadap Karakteristik Jus. Skripsi Program Studi Teknologi Pengan Fakultas teknik. Universitas Pasundan. Bandung.

Andarwulan, N. dan Faradilla, R.H.F. (2012). Pewarna Alami untuk Pangan. (SEAFAST) Center. Institut Pertanian Bogor.

Edinarwati, P. (2006). Pengaruh Konsentrasi Sukrosa dan Konsentrasi Pektin Terhadap Karateristik Selai Lembaran Stroberi (Fragaria vesca L.) Naskah Skripsi S-1. Fakultas Teknik. Universitas Pasundan, Bandung.

Fachruddin, L. (1997). Membuat Aneka Selai. Yogyakarta: Kanisius.

Hadisaputra. (2012). Super Foods. Flash Books . Yogyakarta.

Ismiati. (2013). Budidaya Terong Belanda. Alumni. Jogjakarta.

Isnaini, Lailatul. (2010). "Ekstraksi Pewarna Merah Cair Alami Berantioksidan dari Kelopak Bunga Rosella (Hibiscus sabdariffa L) dan Aplikasinya pada Produk Pangan". Jurnal Teknologi Pertanian Vol. 11 No. 1. Balai Pengkajian Teknologi Pertanian Jawa Timur.

Parimin, S. P. (2007). Jambu Biji :Budi daya dan Ragam Pemanfaatannya. Jakarta: Penebar Swadaya.

Prasetyo, W. (2013). Pengaruh Penambahan Gum Arab Teradap Karakteristik Fisikokimia dan Sensori Fruit Leather Nanas (Ananas comosus L. Merr.) dan Wortel (Daucus carota). Jurnal Teknologi Pertanian. Vol. 15, No. 2 139148. Universitas Sebelas Maret Surakarta.

Putri IR, Basito, Widowati E. (2013). Pengaruh konsentrasi agar-agar dan karagenan terhadap karakteristik fisik, kimia, dan sensori selai lembaran pisang (Musa paradisiaca L.) varietas raja bulu. Jurnal Teknosains Pangan 2(3): $112-120$.

Saati, E. A. (2010). Identifikasi dan Uji Kualitas Pigmen Kulit Buah Naga Merah (Hylocareus costaricensis) Pada Beberapa Umur Simpan dengan Perbedaan Jenis Pelarut. Jurnal GAMMA, Vol. 6, No. 1, p. 25-34.

Saati, E. A. (2011). The Anthocyanin Pigment Of Red Rose Flower As A Potencial Natural Colorant. Proseding WHR 2011 Nominator Poster Presentations in Halal Science \& Research Excellence, di Kuala Lumpur 6-7 April 2011.

Saati, E. A. (2014). Non-Alcoholic Extraction of Rose Pigment as a Halal and Safe Natural Colorant and Bioactive Compound. Journal of Islamic Perspective on Science, Technology and Society, Vol. 2, No. 2, p. 67-68.

Saati, E. A. (2016)a. Identification of Glicon Types in The Crown Flower of Batu Local Roses Using LC-MS Analysis. ARPN Journal of Engineering and Apllied Sciences. ISSN 1819-6608 : Vol. 11, No. 21, November 2016. 
Saati, E. A. (2016)b. Antioxidant Power of Rose of Anthocyanin Pigment. Journal of Engineering and Apllied Sciences. ISSN 1819-6608 : Vol. 11, No. 17, September 2016.

Tranggono, d. (1990). Bahan Tambahan Makanan. Yogyakarta: Pusat Antar Universitas-Pangan dan Gizi, Universitas Gadjah Mada.

Winarno F.G. (2004). Kimia Pangan dan Gizi. PT Gramedia Pustaka Utama. Jakarta.

Winarno, F. (2008). Kimia Pangan dan Gizi: Edisi Terbaru. Jakarta: Gramedia 